\title{
Nitrogen, Phosphorus, and Potassium Flows through the Manure Management Chain in China
}

Bai, Zhaohai; Ma, Lin; Jin, Shuqin; Ma, Wenqi; Velthof, Gerard L.; Oenema, Oene; Liu, Ling; Chadwick, David; Zhang, Fusuo

\section{Environmental Science and Technology}

DOI:

10.1021/acs.est.6b03348

Published: 01/01/2016

Peer reviewed version

Cyswllt i'r cyhoeddiad / Link to publication

Dyfyniad o'r fersiwn a gyhoeddwyd / Citation for published version (APA):

Bai, Z., Ma, L., Jin, S., Ma, W., Velthof, G. L., Oenema, O., Liu, L., Chadwick, D., \& Zhang, F. (2016). Nitrogen, Phosphorus, and Potassium Flows through the Manure Management Chain in China. Environmental Science and Technology, 50(24), 13409-13418.

https://doi.org/10.1021/acs.est.6b03348

\footnotetext{
Hawliau Cyffredinol / General rights

Copyright and moral rights for the publications made accessible in the public portal are retained by the authors and/or other copyright owners and it is a condition of accessing publications that users recognise and abide by the legal requirements associated with these rights.

- Users may download and print one copy of any publication from the public portal for the purpose of private study or research.

- You may not further distribute the material or use it for any profit-making activity or commercial gain

- You may freely distribute the URL identifying the publication in the public portal ?
}

Take down policy

If you believe that this document breaches copyright please contact us providing details, and we will remove access to the work immediately and investigate your claim. 
This document is confidential and is proprietary to the American Chemical Society and its authors. Do not copy or disclose without written permission. If you have received this item in error, notify the sender and delete all copies.

\section{Nitrogen, phosphorus and potassium flows through the manure management chain in China}

\begin{tabular}{|r|l|}
\hline Journal: & Environmental Science \& Technology \\
\hline Manuscript ID & es-2016-033488.R2 \\
\hline Manuscript Type: & Article \\
\hline Date Submitted by the Author: & n/a \\
\hline Complete List of Authors: & $\begin{array}{l}\text { Bai, Zhaohai; The Chinese Academy of Sciences, Key Laboratory of } \\
\text { Agricultural Water Resources, Center for Agricultural Resources Research, } \\
\text { Institute of Genetic and Developmental Biology } \\
\text { Ma, Lin; Institute of Genetic and Developmental Biology, The Chinese } \\
\text { Academy of Sciences, Key Laboratory of Agricultural Water Resources, } \\
\text { Center for Agricultural Resources Research } \\
\text { Jin, Shuqin; Research Center for Rural Economy Ministry of Agriculture } \\
\text { Ma, Wenqi; College of Resources and Environmental Science, Hebei } \\
\text { Agricultural University, } \\
\text { Velthof, Gerard; Wageningen University and Research Center } \\
\text { Oenema, Oene; Wageningen University, Department of Soil Quality } \\
\text { Liu, Ling; The Chinese Academy of Sciences, Center for Agricultural } \\
\text { Resources Research, Institute of Genetic and Developmental Biology } \\
\text { Chadwick, David; Bangor University, School of Environment, Natural } \\
\text { Resources and Geography } \\
\text { Zhang, Fusuo; China agricultural university, }\end{array}$ \\
\hline \hline
\end{tabular}

\section{SCHOLARONE ${ }^{\text {th }}$}

Manuscripts 


\section{Nitrogen, phosphorus and potassium flows through the} 2 manure management chain in China

3 Zhaohai Bai $\uparrow \S$, Lin Ma*†, Shuqin Jin $\perp$, Wenqi Ma//, Gerard L. Velthof $§$, Oene Oenema $\ddagger$,

$4 \quad$ Ling Liu†, David Chadwick $\uparrow \uparrow$, Fusuo Zhang $\phi$

5

$6 \uparrow$ Key Laboratory of Agricultural Water Resources, Center for Agricultural Resources

7 Research, Institute of Genetic and Developmental Biology, The Chinese Academy of Sciences,

8286 Huaizhong Road, Shijiazhuang 050021, Hebei, China;

$9 \S$ Wageningen University and Research, Department of Soil Quality, P.O. Box 47, 6700 AA,

10 Wageningen, The Netherlands;

$11 \perp$ Research Center for Rural Economy Ministry of Agriculture, No.56, Xisizhuanta Hutong,

12 Beijing, 100810, China;

13 // College of Resources \& Environmental Sciences, Agricultural University of Hebei, 14 Baoding 071001, China;

$15 \ddagger$ Wageningen University and Research, Environmental Research P.O. Box 47, 6700 AA, 16 Wageningen, The Netherlands;

$17 \dagger$ School of Environment, Natural Resources and Geography, Bangor University, Bangor, 18 LL57 2UW, UK;

$19 \phi$ College of Resources and Environmental Sciences, China Agriculture University, Beijing 20 100193, P.R. China.

$22 *$ Corresponding author: Lin Ma; Key Laboratory of Agricultural Water Resources, Center for 


\section{Abstract:}

Agricultural Resources Research, Institute of Genetic and Developmental Biology, The Chinese Academy of Sciences, 286 Huaizhong Road, Shijiazhuang 050021, Hebei, China; Phone and fax numbers: 86-(0)311-85810877; email: malin1979@sjziam.ac.cn.

China is the biggest livestock production and largest fertilizer user country in the world. However, quantification of nutrient flows through the manure management chain and their interactions with management-related measures is lacking. Here, we present a detailed analysis of nutrient flows and losses in the "feed intake - excretion - housing - storage - treatment - application" manure-chain, while considering differences between livestock production systems. We estimated the environmental loss from the manure-chain in 2010 to be up to $78 \%$ of the excreted nitrogen, and over $50 \%$ of excreted phosphorus and potassium. Greatest losses occurred from housing and storage stages, via $\mathrm{NH}_{3}$ emissions (39\% of total nitrogen losses), and direct discharge of manure to water bodies or landfill (30-73\% of total nutrient losses). There are large differences between animal production systems, where the landless system has the lowest manure recycling. Scenario analyses for the year 2020 suggest that significant reductions of fertilizer use (27\%-100\%) and nutrient losses (27-56\%) can be achieved through a combination of prohibiting manure discharge, improving manure collection and storages infrastructures, and improving manure application to cropland. We recommend that current policies and subsidies targeted at the fertilizer industry should shift to reduce the cost of manure storage, transport and application. 


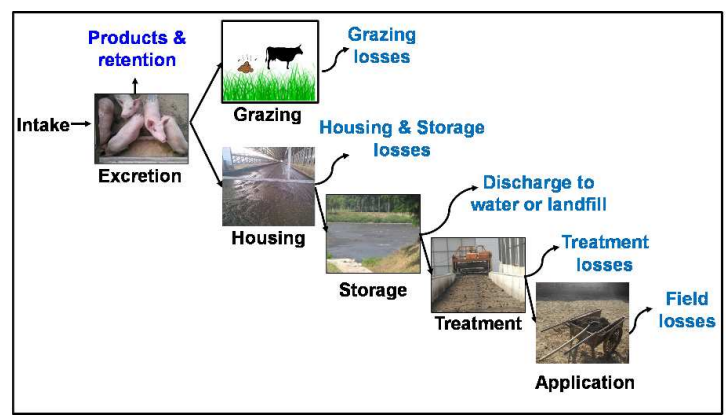




\section{INTRODUCTION}

Intensive livestock production systems have large impacts on water and air quality through emissions of greenhouse gases (GHG) and nutrients (mainly nitrogen $(\mathrm{N})$ and phosphorus $(\mathrm{P})^{1-4}$. The $\mathrm{N}$ and $\mathrm{P}$ emissions originate mainly from livestock excrements. Total livestock excretion in the world is about 80-130 Tg N per year, from which only $20-40 \%$ is efficiently utilized for fertilizing cropland ${ }^{5-6}$. The remainder of the manure $\mathrm{N}$ excreted is emitted to the atmosphere, groundwater or surface waters. However, there are large differences in manure management throughout the world, depending on livestock production system, environmental conditions and governmental policy measures. For example, on average $65 \%$ of excreted $\mathrm{N}$ in animal housing is recycled back to agricultural land in the Europe Union (EU), which is in part a result of strict regulations $^{7}$. At the farm level, there can be large differences. A survey in Africa showed that $6-99 \%$ of collected manure is recycled cropland ${ }^{8}$. In China, a large proportion of manure $\mathrm{N}$ from pig production is lost via direct discharge into water bodies or is landfilled ${ }^{9-10}$.

Recent studies have used material flow and nutrient footprint approaches to quantify $\mathrm{N}$ and/or $\mathrm{P}$ losses and use efficiencies for whole livestock production systems at global level ${ }^{11}$, regional level $\left(\mathrm{EU}^{12,13}\right)$ and national level (United States, USA $\left.{ }^{14}\right)$.

Several models have been developed to estimate the nutrient flows and losses in livestock production, e.g. MITERRA-Europe ${ }^{15}$, NUFER (NUtrient flows in Food chains, Environment and Resources use) ${ }^{16}$, and GAINS (Greenhouse Gas-Air Pollution Interactions and Synergies) ${ }^{17}$. Some other models have been developed to 
estimate single pollutant losses from livestock systems, e.g. ammonia $\left(\mathrm{NH}_{3}\right)$ losses emission from manure management ${ }^{18}$. However, there are no models available yet that can calculate $\mathrm{N}, \mathrm{P}$ and potassium $(\mathrm{K})$ flows and losses in detail for each step in the “feed intake - excretion - housing - manure storage - manure treatment - manure application" chain in a consistent way for the different animal categories and production systems, at the regional level. A further understanding of the manure nutrient flows and losses is important, because previous studies showed that the effects of feeding regimes and manure management practices strongly differ between livestock production systems ${ }^{10,19}$. For example, $\mathrm{N}$ losses from traditional dairy production systems in China, mainly occur through $\mathrm{NH}_{3}$ emissions, and in the industrial dairy feedlots mainly through direct discharge of manure to water bodies or $\operatorname{landfill}^{10}$. Information about the effects of management-related technical measures and their interactions on manure nutrient recycling and subsequent chemical fertilizer needs are still lacking. Such insights are needed for achieving low emission livestock production systems and sustainable agriculture in $\mathrm{China}^{20}$.

China is a major contributor to world livestock production, and both extensive and intensive systems exist ${ }^{21,22}$. Industrial-scale livestock operations are rapidly increasing in their contribution to total livestock production, mainly because of their large production capacity and high feed use efficiency on the farm. However, most of these industrial systems are landless and have limited opportunity to recycle manure nutrients back to crop land. Recently, the Chinese government initiated a plan to stabilize fertilizer consumption by 2020 , the so-called "Zero Fertilizer Increasing by 
$902020 "$ goal $^{20}$. The consumption of $\mathrm{K}$ fertilizers is large ${ }^{22}$ and there are no studies in

91 which the potential of replacing fertilizer $\mathrm{K}$ by manure $\mathrm{K}$ has been assessed.

92 The aim of this study was to estimate the manure N, P and K flows and losses in the

93 "feed intake - excretion - housing - storage - treatment - application" chain for

94 different animal categories and production systems in China for the year 2010, using a

95 modified version of the NUFER model. We developed a ' $\mathrm{K}$ module' and included it in

96 the NUFER model. The analyses were carried out for different animal categories (pigs,

97 layers, broilers, dairy cattle, beef cattle, buffaloes and draught cattle, and sheep and

98 goats) and different production systems (mixed, grazing and landless systems). In

99 addition, five scenarios were explored to assess the potentials for reducing manure $\mathrm{N}$,

$100 \mathrm{P}$ and $\mathrm{K}$ losses and for replacing fertilizer inputs by manure nutrients for the year

1012020.

102

103

MATERIALS AND METHODS:

104 The NUFER model ${ }^{16}$ was further developed and used to estimate N, P and K flows

105 and losses in each step of the manure management chain. This model uses a mass

106 balance approach; it starts with an estimation of total feed nutrients intake rate for the

107 different animal categories. The calculation methods and parameters used are

108 presented in detail in the Supplementary Information (SI). Below a summary is given.

Description of livestock production systems

111 In total, six animal categories and three typical (for China) production systems were 
112 distinguished. The six main animal categories include pigs, layers, broilers, dairy 113 cattle, other cattle (beef cattle, buffaloes and draught cattle), and sheep and goats.

114 Together these categories generate most of the manure in China ${ }^{23}$. For each animal 115 category we distinguished three different production systems, according to the feeding 116 regimes, manure management practices and available statistical data, i.e. mixed 117 cropping-livestock system, grazing production system and landless production system 118 (Table S1). Mixed cropping-livestock systems are basically the traditional production 119 system; the solid part of excretion is collected and mainly applied to cereal crops, 120 while the liquid fraction is only partly collected and the remainder is lost by leaching 121 into the subsoil and wider environment. Grazing systems are mainly found in Gansu, 122 Xinjiang, Ningxia, Tibet, and Inner-Mongolia provinces ${ }^{16}$, see also Fig S1. Most of 123 the excretion is directly dropped to grassland, during the grazing period. The solid 124 part of the excretion is collected when the animals are kept in confinement; however, 125 the liquid part is mainly leached to the subsoil. The industrial production systems are 126 landless; a large fraction of the manure produced in landless systems is discharged 127 into surface waters, with or without some treatment, or dumped into landfills. A part 128 of the solid manure is exported to nearby farms growing vegetables and fruits 129 following composting treatment. The livestock production structure (i.e. the 130 percentage of each system per animal category) in 2010 was derived from national 131 statistics ${ }^{21}$. Information about the definitions and animal population of each 132 production system is listed in Tables S1 and S2 in the SI. 
134

135

136

137

138

139

140

141

142

\section{Feed and nutrient intake calculation}

Total feed intake was calculated from the number of livestock for each category and the feed requirements per animal category. Feed intake was estimated on the basis of the energy requirements for maintenance, growth (live weight gain) and production (Bai et al. 2013; 2014) $)^{9,10}$. The number of animals per category was derived from MOA statistics ${ }^{21}$ and the FAO database ${ }^{22}$. For pigs and broilers, the number of slaughtered animals was used, and for dairy and layers, the numbers of producing animals ${ }^{22}$. Stock numbers were used for beef cattle, buffaloes and draught cattle, and sheep and goat production ${ }^{22}$. Feed intake was estimated from energy requirements per animal category and feed supply according to data from the FAO database and farm

surveys ${ }^{16,22}$. Feed-specific N, P and K contents were derived from literature (Table S9). The excretion of nutrients was calculated as the difference between feed nutrient intake and the nutrient retained in products (milk, eggs) and in body weight gain (meat, blood, bones and hides).

\section{Nutrient retention by livestock}

Nutrient (N, P and K) retention was calculated at the herd level per animal category (considering the breeding and backup animals). In a simple form (for one animal category, production system), the equation for estimating retention showed as below:

Oa nutrient in products $=($ Yield $+\mathrm{BWG}) *$ Animal number $*$ Nutrient content

Where, $\mathrm{Oa}$ nutrient in products is the total amount of $\mathrm{N}, \mathrm{P}$ or $\mathrm{K}$ in animal body weight gain, milk and egg, in kg per year; Yield is the yield of animal products (milk and eggs), in 
$156 \mathrm{~kg} \mathrm{head}^{-1} \mathrm{yr}^{-1}$; BWG is the body weight gain of animals, including meat, bones, blood 157 and hides, in $\mathrm{kg} \mathrm{head}^{-1} \mathrm{yr}^{-1}$ (Table S5-7); Nutrient content is the $\mathrm{N}$, P or K content of 158 milk, eggs and BWG, in $\mathrm{kg} \mathrm{kg}^{-1}$. The $\mathrm{N}$ and $\mathrm{P}$ contents were derived from the NUFER database $^{16}$. The K content was derived from literature (Table S8).

160

\section{Nutrient excretion}

162

163

164

Nutrient excretion was calculated as the difference between total nutrient intake and nutrient retention in milk, egg and BWG. In a simple form:

$\mathrm{Oa}_{\text {nutrient excretion }}=\mathrm{Ia}_{\text {nutrient intake }}-\mathrm{Oa}_{\text {nutrient in products }}-\mathrm{Oa}_{\text {nutrient in dead animals }}$

Where, $\mathrm{Oa}$ nutrient excretion is the amount of nutrient (N,P and $\mathrm{K}$ ) excreted per animal category, in $\mathrm{kg} \mathrm{yr}^{-1}$; $\mathrm{Oa}_{\text {nutrient in products }}$ is the amount of $\mathrm{N}, \mathrm{P}$ and $\mathrm{K}$ output in milk, eggs

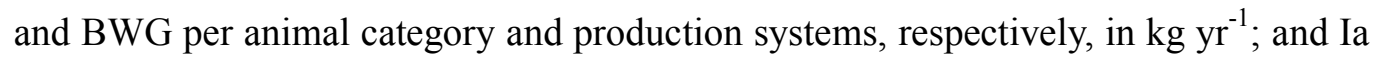
nutrient intake represents the amount of $\mathrm{N}, \mathrm{P}$ and $\mathrm{K}$ in feed intake per animal category and production system, in $\mathrm{kg} \mathrm{yr}^{-1}$. Corrections were made for animals that died during the production cycle ( $\mathrm{Oa}$ nutrient in dead animals); it was assumed that the nutrients in dead animals ended up landfill, possibly following incineration.

\section{Nutrient use efficiency and manure nutrient recycling efficiency}

The $\mathrm{N}, \mathrm{P}$ and $\mathrm{K}$ use efficiencies and manure nutrient recycling efficiency were calculated at herd level as follows:

Nutrient use efficiency $=\left(\mathrm{Oa}\right.$ nutrient in products $\left./ \mathrm{Ia}_{\text {nutrient intake }}\right) * 100 \%$

Manure nutrient recycling efficiency $=\left(\mathrm{Oa}_{\text {nutrient recycled }} / \mathrm{Oa}_{\text {nutrient excretion }}\right) * 100 \%[4]$ 
178 Manure nutrient recycling efficiency is the percentage of excreted $\mathrm{N}, \mathrm{P}$ and $\mathrm{K}$

179 recycled to agricultural land per animal category and production system. Oa nutrient 180 recycled is sum of the amounts of $\mathrm{N}, \mathrm{P}$ and $\mathrm{K}$ deposited during grazing and applied to

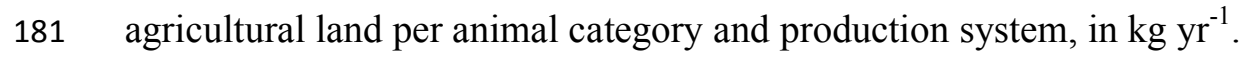

\section{Fertilizer replacement by manure}

The potential to replace fertilizer by manure was calculated as follows:

Fertilizer replacement $=\{($ Manure application $*$ Fertilizer value $) /$ Fertilizer application $\} * 100 \%$

Where, Fertilizer replacement is the amount of fertilizer N, P and $\mathrm{K}$ that can be replaced by manure $\mathrm{N}, \mathrm{P}$ and $\mathrm{K}$, in $\%$; Manure application is the amount of manure $\mathrm{N}$,

$\mathrm{P}$ and $\mathrm{K}$ applied to cropland (excluding manure $\mathrm{N}, \mathrm{P}$ and $\mathrm{K}$ deposited during grazing because essentially no fertilizer is applied to grassland in China), in $\mathrm{kg} \mathrm{yr}^{-1}$; Fertilizer value is the proportion of the manure $\mathrm{N}, \mathrm{P}$ and $\mathrm{K}$ available to crops in the first season, in \% (Table S13); Fertilizer application is the amount of fertilizer N, P and K applied to cropland in 2020, in $\mathrm{kg} \mathrm{yr}^{-1}$. Fertilizer values differ per animal manure type and nutrient. The total fertilizer application in 2020 was estimated from the total $\mathrm{N}, \mathrm{P}$ and

$195 \mathrm{~K}$ fertilizer application in $2015^{22}$, and the expected increase in fertilizer use during the 196 period 2015-2020

\section{Scenarios for 2020}

199 A total of five future scenarios were considered to explore the potential for reducing 
nutrient losses from the manure management chain and the potential for replacing fertilizer nutrients by manure nutrients, The year 2010 was used as the reference year because of data availability, and 2020 was set as a target year, because of China's aim to achieve "Zero Fertilizer Increase Use" by the end of $2020^{20}$. According to the projections by FAO, the total demand for animal products in China will increase by $17 \%$ for pork and eggs, $33 \%$ for chicken meat, $24 \%$ for milk, $24 \%$ for beef, and $22 \%$ for mutton ${ }^{24}$ between 2010 and 2020.

S0 - Business as usual (BAU).Production of animal products was based on linear extrapolations of the projections of FAO between 2010 and $2020^{24}$. In this scenario, we assumed that the increase in the demand for livestock products would be produced in land-less systems. We also assumed that the productivity, feed composition and manure management practices of each system would be the same as in 2010 , which may provide a conservative estimate of manure nutrient production, flows and losses. Changes in animal numbers between 2010 and 2020 are shown in Table S2.

S1 - Prohibit the discharge of manure. This scenario builds on S0, but includes an adoption of stricter manure management regulations ${ }^{25}$. We assumed that the discharge of manure to surface water or landfill will be prohibited in the industrial animal production systems.

\section{S2 - Improving manure collection and nutrient preservation in housing and} storage systems. This scenario builds on S0, and assumes in addition that the $\mathrm{N}$ losses (in \% of excreted $\mathrm{N}$ ) from animal housing and storage systems will decrease to current mean levels in the European Union (EU), i.e., the average $\mathrm{N}$ losses via $\mathrm{NH}_{3}$, 
$222 \mathrm{~N}_{2} \mathrm{O}$ and $\mathrm{N}_{2}$ emissions to air and via $\mathrm{N}$ leaching will decrease to $5 \%, 1 \%, 5 \%$ and $0 \%$

223 of the amount of manure $\mathrm{N}$ excreted, respectively ${ }^{26}$. Further, there will be no losses of

224 manure $\mathrm{P}$ and $\mathrm{K}$ from industrial production system due to improved containment of

225 manures.

226 S3 - Improving manure application. This scenario builds also on S0. Current crop

227 production in China does not account for nutrients supplied by manure, especially in

228 cash crop production (e.g. in greenhouse vegetables and orchards) in which the

229 amounts of nutrient applied with fertilizer and manure far exceed the nutrient demand

230 of the crop $^{27}$. We assume that the available nutrients in manures applied to cropland

231 replace fertilizer nutrients, using manure-specific fertilizer nutrient replacement

232 values. Further, we assumed that low ammonia emission manure application methods

233 will be adopted, i.e. slurry injection and rapid incorporation of solid manures, by

234 which the $\mathrm{N}$ fertilizer replacement value of manures will increase to $55 \%$ for cattle

235 slurry, $75 \%$ for pig slurry and $85 \%$ for poultry manure (Table S13).

236 S4 - Combination of S1-S3. In this scenario, the technologies assumed for S1, S2

237 and S3 are combined. Further, we assumed that the technologies can be applied as

238 complements to each other.

\section{RESULTS}

\section{Nutrient flows through the whole manure chain}

242 The N, P and K flows in the manure chain for the year 2010 are presented in Fig 1.

243 Total feed $\mathrm{N}$ intake amounted to $26.0 \mathrm{Tg}$, from which $22.8 \mathrm{Tg} \mathrm{N}$ was excreted $(3.5 \mathrm{Tg}$ 
$244 \mathrm{~N}$ was deposited in the field during grazing and 19.3 Tg $\mathrm{N}$ was excreted in housing 245 systems). Total $\mathrm{N}$ losses via $\mathrm{NH}_{3}$ emission, denitrification, and leaching from housing 246 amounted to $8.3 \mathrm{Tg}$. In addition, a significant amount $(5.4 \mathrm{Tg} \mathrm{N})$ was lost via 247 discharge to water bodies or landfill. The collected manure (5.6 Tg N) was treated (by 248 composting, digestion or separation), which led to another $\mathrm{N}$ loss of $1.6 \mathrm{Tg}$. In total, 249 only $4.0 \mathrm{Tg}$ manure $\mathrm{N}$ was applied to cropland, i.e., $68 \%$ to cash crops and $32 \%$ to 250 cereals crops. Total $\mathrm{N}$ losses via gaseous emissions, leaching, runoff and erosion 251 during grazing and after manure application were estimated at $1.5 \mathrm{Tg}$. The remaining 252 manure $\mathrm{N}$ was either taken up by crops or accumulated in the soil. In total $78 \%(17.8$ $253 \mathrm{Tg} \mathrm{N}$, including field losses) of the excreted $\mathrm{N}$ was lost to the environment from the 254 different stages of the manure management chain. The highest losses occurred from 255 housing and manure storages ( $47 \%$ of total $\mathrm{N}$ loss), followed by discharge of manure manure application $(8 \%)$ and grazing $(6 \%)$.

\section{Contributions of different animal categories and production systems}

265 Fig 2 presents the relative contributions of different production systems and animal 
categories to total manure nutrient flows and losses. Clearly, the manure nutrient flows were largest in the mixed production systems, accounting for 53\%-57\% of total nutrient excretion. Nutrient excretion was smallest in grazing systems. Nutrient recycling was smallest in the landless production system and largest in grazing systems. The $\mathrm{P}$ losses were relatively low in grazing systems $(3 \%$ of total manure $\mathrm{P}$ losses), and high in mixed and landless production systems. Manure production was highest for the category beef cattle, buffaloes and draught cattle, followed by sheep and goats and then pigs. Pigs excreted two times more P than sheep and goats. The contributions of layers, broilers and dairy cattle to manure nutrient flows were relatively small (Figure 2).

\section{Nutrient use efficiencies at herd level}

The average feed nutrient use efficiency at herd level, across all livestock categories, was $11 \%$ for $\mathrm{N}$ (NUE), $14 \%$ for P (PUE), and $2.7 \%$ for K (KUE). The low KUE was related to the low $\mathrm{K}$ contents of meat, milk and egg. The landless production systems had much higher nutrient use efficiencies than the other two production systems (Figure 3a). For example, the NUE of landless systems was $21 \%$, almost six times that of grazing systems. The mixed production system was more efficient than the grazing system to convert feed $\mathrm{N}$ and $\mathrm{K}$ into products (Figure 3a), but the grazing system had a higher PUE than the mixed system.

The NUE at herd level was highest for broilers (40\%) and lowest for beef cattle, buffaloes and draught cattle (2.3\%). Similar results were found for PUE and KUE. 
288

289

290

291

292

293

294

295

296

297

298

299

300

301

302

303

304

305

306

307

308

309

The monogastric animals (broilers, layers and pigs) were more efficient than the ruminant livestock categories (dairy cattle, beef cattle, buffaloes and draught cattle, sheep and goats) in utilizing feed nutrients (Fig 3b).

\section{Manure nutrient recycling efficiency}

The manure $\mathrm{N}$ recycling efficiency decreased in the order of grazing $(54 \%)>$ mixed $(34 \%)>$ landless $(19 \%)$ production system. Similar trends were found for manure P and $\mathrm{K}$ recycling efficiencies (Figs. $3 \mathrm{c}$ and $3 \mathrm{~d}$ ). The manure nutrient recycling efficiency of grazing systems was about two times greater than that of the landless system (Fig 3c). The manure nutrient recycling efficiency ranged from 20 to $40 \%$ for $\mathrm{N}$, 30 to $62 \%$ for $\mathrm{P}$, and 30 to $65 \%$ for $\mathrm{K}$, depending on animal category and production system. The manure nutrient recycling was higher for ruminant animals than for monogastric animals (Fig 3).

\section{Losses of nutrients from the manure management chain}

Total $\mathrm{N}$ losses from the whole manure management chain amounted to $17.8 \mathrm{Tg}$ in 2010 (Fig 4). Emission of $\mathrm{NH}_{3}\left(6.9 \mathrm{Tg} ; 13 \mathrm{~kg} \mathrm{~N}\right.$ ha $^{-1}$ agricultural land) and discharge of manure to surface waters or landfill $\left(5.4 \mathrm{Tg}, 11 \mathrm{~kg} \mathrm{~N}^{-1}\right.$ agricultural land) were the major $\mathrm{N}$ losses pathways. Losses via leaching, runoff and erosion (L\&R\&E) amounted to $3.4 \mathrm{Tg} \mathrm{N}\left(6.6 \mathrm{~kg} \mathrm{~N} \mathrm{ha}^{-1}\right.$ agricultural land). Losses via denitrification and $\mathrm{N}_{2} \mathrm{O}$ emissions were 1.8 (3.5 $\mathrm{kg} \mathrm{N} \mathrm{ha}^{-1}$ agricultural land) and $0.3 \mathrm{Tg}\left(0.5 \mathrm{~kg} \mathrm{~N} \mathrm{ha}^{-1}\right.$ agricultural land, respectively. Direct discharge of manure to water bodies or landfill 
310

311

312

313

314

315

316

317

318

319

320

321

322

323

324

325

326

327

328

329

330

331

contributed $78 \%$ to the total manure $\mathrm{P}$ losses and $61 \%$ to the total manure $\mathrm{K}$ losses.

The total average $\mathrm{N}$ loss was $35 \mathrm{~kg} \mathrm{~N} \mathrm{ha}^{-1}$ cropland. Average $\mathrm{P}$ and $\mathrm{K}$ losses were 5.0kg P ha ${ }^{-1}$ and $16 \mathrm{~kg} \mathrm{~K} \mathrm{ha}^{-1}$ cropland, respectively.

Animal production systems differed in nutrient loss pathways (Fig 4). Most of the $\mathrm{N}$ losses via $\mathrm{NH}_{3}, \mathrm{~N}_{2} \mathrm{O}$ and $\mathrm{N}_{2}$ emissions to air, and via leaching, runoff and erosion to water bodies occurred in mixed production systems. Direct discharge of manure into watercourses or landfill represented the largest $\mathrm{N}$ loss pathways in landless production system, while there was no discharge of manure nutrient in grazing systems. Ammonia emissions were the largest $\mathrm{N}$ loss pathway in mixed systems. Highest $\mathrm{P}$ losses were found in pig and poultry production and in landless production systems. Monogastric animals contributed around $50 \%$ to the $\mathrm{N}$ losses via direct discharge, while ruminant animals were the dominant source of $\mathrm{N}$ losses via leaching, runoff and erosion.

\section{Scenarios for 2020}

In the S0-business as usual scenario, manure management contributed to reduce $1 \%$ of $\mathrm{N}$ fertilizer, $12 \%$ of $\mathrm{P}$ fertilizer, and $34 \%$ of $\mathrm{K}$ fertilizer (Fig 5). The changes in fertilizer replacement are relatively small in the scenario where direct discharge of manure was prohibited (S1). This is because most of the recycled manure was applied to cash crops; these crops are over-fertilized and more manure does not affect the fertilizer use. Also, a ban on direct discharge is not easy to implement, as it will require additional investments in manure storage, transportation and spreading 
332 infrastructure, thus increasing the cost. Improving manure collection in housing and 333 storage systems (S2) has also little impact on fertilizer replacement rates, for similar 334 reasoning (Fig S2). Improving manure application strategies (S3) seems more 335 promising than the other two single options; it increases the $\mathrm{N}$ fertilizer replacement to $11 \%$, the $\mathrm{P}$ fertilizer replacement to $43 \%$ and $\mathrm{K}$ fertilizer replacement to $76 \%$.

In $\mathrm{S} 0$, the total $\mathrm{N}$ losses from the whole manure management chain will increase by $15 \%$ in 2020 compared with 2010 . The total $\mathrm{P}$ and $\mathrm{K}$ losses will increase by $12 \%$ and $22 \%$, respectively (Fig $5 b$ ). In all single options, S1 is more effective than S2 and S3 in reducing nutrient losses. The $\mathrm{N}$ losses can be reduced by $14 \%, \mathrm{P}$ losses by $47 \%$ and $\mathrm{K}$ losses by $40 \%$ through the prohibition of direct discharges of manure to surface water or landfill and the application of manure to agricultural land. The integrated option (S4) is more effective than the single options, both in reducing fertilizer input and reducing manure nutrient losses. In the combination scenario (S4), 27\% of the chemical $\mathrm{N}$ fertilizer, $86 \%$ of the chemical $\mathrm{P}$ fertilizer and all of the chemical $\mathrm{K}$ fertilizer can be replaced by optimizing the management of manure. At the same time, manure $\mathrm{N}$ losses can be reduced by $27 \%$, P losses by $56 \%$ and $\mathrm{K}$ losses by $53 \%$, compared with those in the S0 scenario (Fig 5).

\section{DISCUSSION}

This is the first study on $\mathrm{N}, \mathrm{P}$ and $\mathrm{K}$ flows through the whole manure management chain of different livestock categories and production systems in China, that quantifies the impacts of management and technical measures to reduce $\mathrm{N}, \mathrm{P}$ and $\mathrm{K}$ 
354

355

356

357

358

359

360

361

362

363

364

365

366

367

368

369

370

371

372

373

374

375 Manure nutrient excretion, losses and recycling in China focused in China in the future. fertilizer replacement values of different manures.

losses. In 2010, $33 \%$ of the excreted N, $50 \%$ of excreted P and $53 \%$ of excreted $\mathrm{K}$ were recycled, with the rest being lost to the environment at different stages of the manure chain. In contrast to many other countries in the world, the greatest losses occurred via direct discharge of manure to watercourses and landfill. Highest nutrient losses occurred in mixed production systems with other cattle (beef and draught cattle and buffaloes). The results of this study indicate the key stages (animal housing and manure storages), production systems (landless systems) and livestock categories (other cattle and pigs) where policy and research on manure management should be

Through analysis of the impacts of management-related technical measures, we found that significant reductions of nutrient losses (27-56\%) and inputs of fertilizers (27\%-100\%) could be achieved by 2020 . To achieve such reductions, polices for prohibiting direct discharge of manures into watercourses and landfill, improving manure collection and storage infrastructure, and improving manure application methods should be coordinated in the future. The main uncertainties in the results of this study are related to the robustness of the statistical and literature data and the emission factors used. Additional farm level monitoring and measurements of nutrient losses are needed in the future to estimate the nutrient flows more accurately, e.g. gaseous emissions and leaching of nutrients from different livestock systems, and 
Our estimate of total $\mathrm{N}$ excretion in $2010(22.8 \mathrm{Tg})$ was higher than the net $\mathrm{N}$ excretion of some other studies, such as $16 \mathrm{Tg} \mathrm{N}$ in $2010^{23}, 17 \mathrm{Tg} \mathrm{N}$ in $2005^{28}$, and 19 $\operatorname{Tg} \mathrm{N}$ in $2005^{16}$. These other studies presented the net excretion only, i.e., they corrected the total excretion for gaseous $\mathrm{N}$ losses in housing and storages ${ }^{16,23,28}$. The average gross $\mathrm{N}$ and $\mathrm{P}$ excretions per animal category were rather similar to reported gross nutrient excretion rates for the $\mathrm{EU}^{29}$ (Table S17). Total excretion was $4.6 \mathrm{Tg}$ for $\mathrm{P}$ and 16.2 $\mathrm{Tg}$ for $\mathrm{K}$ in 2010, which is rather similar to those of previous studies, i.e. 5.2 $\mathrm{Tg} \mathrm{P}$ in $2010^{23}, 4.4 \mathrm{Tg} \mathrm{P}$ in $2005^{16}$, and $14 \mathrm{Tg} \mathrm{K}$ in $2005^{28}$.

The estimated $\mathrm{NH}_{3}$ emissions $\left(6.9 \mathrm{Tg} \mathrm{NH}_{3}-\mathrm{N}\right)$ and $\mathrm{N}_{2} \mathrm{O}$ emissions $\left(0.3 \mathrm{Tg} \mathrm{N}_{2} \mathrm{O}-\mathrm{N}\right)$ were higher than the estimates of other studies $\left(5.3 \mathrm{Tg} \mathrm{NH}_{3}-\mathrm{N}\right.$ in $2006^{30,}$ and $0.2 \mathrm{Tg}$ $\mathrm{N}_{2} \mathrm{O}-\mathrm{N}$ in $2007^{31}$ ). These differences are partly because net $\mathrm{N}$ excretion (excluding gaseous $\mathrm{N}$ losses from housing) was used in one of the previous studies, and partly because $\mathrm{N}$ losses following manure application were not included in the other study ${ }^{23}$. In our study, $7.5 \mathrm{Tg}$ manure $\mathrm{N}$ (representing $33 \%$ of excreted $\mathrm{N}$ ) was either deposited in grassland by grazing livestock, or applied to cropland (Fig 1). This amount is similar to estimate provided in the study of Ma et al $(2010){ }^{16}$, who reported that $32 \%$ of the excreted $\mathrm{N}$ was recycled in 2005 , but lower than that of Liu et al $(2010)^{28}$, who reported that more than $50 \%$ of the excreted $\mathrm{N}$ was recycled in 2002 . The latter study did not consider $\mathrm{N}$ losses in all stages of the manure management chain and therefore overestimated the amount of manure recycled. About $50 \%$ of the excreted $\mathrm{P}$ was recycled, which is similar $(45 \%)$ to that reported by Liu et al $(2016)^{32}$. Our results suggest that around $8.7 \mathrm{Tg} \mathrm{K}$ was recycled, out of the $16 \mathrm{Tg} \mathrm{K}$ excreted in 2010 .. A 
nearly similar amounts of $\mathrm{K}$ excreted was lost via direct discharge of manure to water bodies or landfill (61\%) and leaching to the sub-soil (39\%). Leaching coefficient for $\mathrm{K}$ were derived from composted manure (Table S12), and applied to the housing, storage and treatment sector for the other manure types of manure, due to lack of data. As composted manure contains relatively lower $\mathrm{K}$ in solution, our estimation for $\mathrm{K}$ leaching may be relatively low.

\section{Comparison with manure management in other countries}

About $33 \%$ of the excreted $\mathrm{N}$ and $50 \%$ of the excreted $\mathrm{P}$ were utilized in China in 2010 (Fig 1). Table 1 shows that these percentages were smaller than those reported for USA $\left(75 \%\right.$ of the manure $\mathrm{N}$ and $\mathrm{P}$ is recycled ${ }^{33,34}$, the $\mathrm{EU}(80 \%$ of the manure $\mathrm{N}$ and almost $100 \%$ of the manure $\mathrm{P}$ is recycled $\left.{ }^{12,35}\right)$, and Japan $(70 \%$ of the manure $\mathrm{N}$ and $80 \%$ of the manure $\mathrm{P}$ is recycled ${ }^{36,37}$ ). The differences between China and these other countries are mainly related to environmental regulations. Manure storage and application to agricultural land is regulated in the EU (e.g. Nitrates Directive, Water Framework Directive, and National Emission Ceiling Directive) ${ }^{7}$. The Nitrates Directive regulates the use of $\mathrm{N}$ in agriculture, especially through designation of "Nitrate Vulnerable Zones" and establishment of Action Plans in these areas, e.g. the maximum $\mathrm{N}$ applied via livestock manure shall not exceed $170 \mathrm{~kg}^{-1} \mathrm{ha}^{-1} \mathrm{yr}^{-1}$, and there are 'closed periods' for manure and fertilizer applications, and obligation for leak-tight manure storages with storage capacity per farm of $6-9$ months ${ }^{38}$. The zero-discharge manure systems in USA regulate for manure storage, land application 
420

421

422

423

424

425

426

427

428

429

430

431

432

433

434

435

436

437

438

439 440 greenhouse vegetable production systems ${ }^{27}$. Although production is high in these 441 systems, the high fertilizer applications rates suggest that manure applied to these

and whole-farm nutrient management planning, resulting in a higher manure recycle efficiency than in China ${ }^{39,40}$ (Table 1). Incentives and taxes can have an important role within some of these policies; for example excess phosphate on farms in the Netherlands was taxed at 9.08 euro for each additional kilogram that exceeds a defined limit ${ }^{42}$ until 2006 However, until a new policy was initiated in 2014 , to control the environmental problems resulting from industrial livestock production systems ${ }^{25}$, there has been little in the way of manure regulations in China. Direct discharge of manure to water bodies is still a major loss pathway. Discharge of manure is forbidden in the EU and USA because of the implementation of the Nitrates Directive in $\mathrm{EU}^{42}$ and specific member states resolutions ${ }^{43}$ and USA federal regulations ${ }^{39,40}$. Current polices in China mainly focus on manure processing and treatment, to promote recycling of manure ${ }^{44}$. However, our results show that the amount of manure that is treated and subsequently applied to crops only represents a small part of the excreted amount of nutrients (Fig 1). Hence, the effectiveness of these policies is still low.

\section{Implications for future manure management}

Grassland is extensively managed in China, barely receiving any fertilizers. Hence, improved recycling of manure from animal confinement in grazing systems will not replace fertilizer, but yet may improve pasture production. In contrast, fertilizer and manure $\mathrm{P}$ application rates of 261 and $310 \mathrm{~kg} \mathrm{P} \mathrm{ha}^{-1}$ year ${ }^{-1}$ have been reported for 
442

443

444

445

446

447

cash crops did not replace much fertilizer. Only manure nutrients applied to cereal crops were considered to replace fertilizer nutrients in this study. Yet, there is a large potential for replacing fertilizer NPK by manure NPK.

In 2020, the total nutrient excretion will amount to $26 \mathrm{Tg} \mathrm{N}, 5.2 \mathrm{Tg} \mathrm{P}$ and $19 \mathrm{Tg} \mathrm{K}$. Results presented in Fig 5 indicate that the objectives of "Zero Fertilizer Increasing by 2020 " can be achieved, and that fertilizer use can be reduced by $27 \%$ for $\mathrm{N}, 82 \%$ for $\mathrm{P}$ and $100 \%$ for $\mathrm{K}$ if the integration of manure management options (S4) can be implemented successfully. Even more fertilizer can be saved if over-fertilization is decreased through the implementation of balanced fertilization ${ }^{45}$.

Recycling of manure is not only environmentally beneficial, through the mitigation of nutrient losses, it is also economically profitable. The annual value of manure nutrient in China is equivalent to 190 billion Yuan (roughly 25 billion Euros), based on the prices of $\mathrm{N}, \mathrm{P}$, and $\mathrm{K}$ in fertilizers ${ }^{23}$, and the availability of $\mathrm{N}, \mathrm{P}$ and $\mathrm{K}$ present in animal manure. However, the cost to manure application to crop land is higher than the cost of fertilizer application. In 2015, around 100 billion Yuan of subsidies (equivalent to 13 billion Euros), was provided to the fertilizer industry in China. Redirecting these subsidies for the fertilizer industry towards manure storage infrastructure, manure transportation and manure application would promote more sustainable use of manure nutrients in the future.

There are also other barriers to recycling manures nutrients to agricultural land effectively and hence reduce losses, e.g. the lack of information about manure nutrient contents and their bioavailability, a shortage of machines to transport and apply 
manure, the in-efficient extension services ${ }^{23}$, and poor infrastructure in terms of housing and storage systems. More studies are required to improve the accuracy of the estimations of nutrient losses and nutrient efficiency in the whole manure chain. In particular, information is needed on the fertilizer replacement value and nutrient availabilities of different manure types applied to the major crops in typical soil and climates in China, to provide the evidence base for a manure management recommendation system. Further investments are needed to improve the infrastructure and management of the farms.

Extensive livestock systems are generally found in remote areas in China, e.g. in Northwest where land degradation is serious, in part because of overgrazing ${ }^{47}$. Intensive livestock production tends to cluster in locations with cost advantages (often close to cities) where insufficient land is available for the recycling of waste from livestock. This may lead to an overload of manure nutrient in these regions. A regional specific analysis is needed to propose region-specific strategies, for effective manure use and mitigation of nutrient losses ${ }^{48}$. There are also other potential environmental problems related to manure management, e.g. antibiotics and heavy metals are of concern. Residues of veterinary antibiotics have been detected in manures and surface water around livestock production farms ${ }^{49,50}$, and even in the urine samples of children $^{51}$. These problems should also be considered through manure chain management strategies.

To conclude, only $33 \%$ of the excreted $\mathrm{N}$ is recycled, which is less than has been estimated in previous studies. Further, $78 \%$ of the excreted $\mathrm{N}$ by livestock in China is 
486

487

488

489

490

491

492

493

494

495

496

497

498

499

500

501

502

503

504

505

506

lost to the environment (including losses after manure application to land, accounted for $11 \%$ of total $\mathrm{N}$ excretion). Nutrient use efficiencies and manure recycling efficiencies differed greatly between systems and animal categories. There is considerable potential to reduce NPK losses from the manure management chain, and to increase the amount of manure applied to crop land and replace fertilizer NPK through adopting integrated options. However, to improve manure utilization, large changes and investments to livestock farm infrastructure, i.e. animal housing, manure storage, and facilities for manure transportation and application, are needed. An integrated manure and fertilizer nutrient recommendation system has to be developed that takes account of the total nutrient and available nutrient content of manures. Finally, the improved knowledge needs to be disseminated to farmers. .

\section{ACKNOWLEDGMENTS}

This work was financially supported by the National Natural Science Foundation of China (31572210), the Hundred Talent Program of the Chinese Academy of Sciences, President's International Fellowship Initiative, PIFI of the Chinese Academy of Science (2016DE008 and 2016VBA073), the UK-China Virtual Joint Centre for Improved Nitrogen Agronomy (CINAg) funded by the Newton Fund via UK BBSRC/NERC (BB/N013468/1). DC also acknowledges SAIN for supporting his contribution. 
507

508

509

510

511

512

513

514

515

516

517

518

519

520

521

522

523

524

525

526

527

528

\section{REFERENCES}

1. Bouwman, L.; Goldewijk, K. K.; Van Der Hoek, K. W.; Beusen, A. H.; Van Vuuren, D. P.; Willems, J.; Rufino, M. C.; Stehfest, E. Exploring global changes in nitrogen and phosphorus cycles in agriculture induced by livestock production over the 1900-2050 period. Proc. Natl. Acad. Sci. USA. 2013, 110(52), 20882-20887.

2. Gerber, P. J.; Steinfeld, H.; Henderson, B.; Mottet, A.; Opio, C.; Dijkman, J.; Falcucci, A.; Tempio, G. Tackling climate change through livestock: a global assessment of emissions and mitigation opportunities. Food and Agriculture Organization of the United Nations (FAO), Rome, 2013.

3. Sutton, M. A.; Bleeker, A.; Howard, C. M.; Bekunda, M.; Grizzetti, B.; Vries, W. D.; van Grinsven, H. J. M.; Abrol, Y. P.; Adhya, T. K.; Billen, G.; Davidson, E. A.; Datta, A.; Diaz, R.; Erisman, J. W.; Liu, X. J.; Oenema, O.; Palm, C.; Raghuram, N.; Reis, S.;Scholz, R. W.; Sims, T.; Westhoek, H.; Zhang, F. S. Our Nutrient World: the challenge to produce more food and energy with less pollution. Centre for Ecology and Hydrology (CEH), Edinburgh, U.K., 2013; pp114.

4. Steinfeld, H.; Gerber, P.; Wassenaar, T.; Castel, V.; Rosales, M.; Haan, C. D. Livestock's long shadow: environmental issues and options. Food and Agriculture Organization of the United Nations (FAO), Rome, 2006.

5. Sheldrick, W.; Syers, J. K.; Lingard, J. Contribution of livestock excreta to nutrient balances. Nutr. Cycling. Agroecosyst. 2003, 66(2), 119-131. 
529

530

531

532

533

534

535

536

537

538

539

540

541

542

543

544

545

546

547

548

549

550

6. Oenema, O.; Wrage, N.; Velthof, G. L.; van Groenigen, J. W.; Dolfing, J.; Kuikman, P. J. Trends in global nitrous oxide emissions from animal production systems. Nutr. Cycling. Agroecosyst. 2005, 72(1), 51-65.

7. Oenema, O.; Oudendag, D.; Velthof, G. L. Nutrient losses from manure management in the European Union. Livest. Sci. 2007, 112(3), 261-272.

8. Rufino, M. C.; Rowe, E. C.; Delve, R. J.; Giller, K. E. Nitrogen cycling efficiencies through resource-poor African crop-livestock systems. Agr. Ecosyst. Environ. 2006, 112(4), 261-282.

9. Bai, Z. H.; Ma, L.; Qin, W.; Chen, Q.; Oenema, O.; Zhang, F. S. Changes in pig production in China and their effects on nitrogen and phosphorus use and losses. Environ. Sci. Technol. 2014, 48(21), 12742-12749.

10. Bai, Z. H.; Ma, L.; Oenema, O.; Chen, Q.; Zhang, F. S. Nitrogen and phosphorus use efficiencies in dairy production in China. J. Environ. Qual. 2013, 42(4), 990-1001.

11. Sutton, M. A.; Howard, C. M.; Erisman, J. W.; Bleeker, A.; Billen, G.; Grennfelt, P.; Grinsven, H. V.; Grizzetti, B. The European nitrogen assessment: sources, effects and policy perspectives. Cambridge University Press: Cambridge, U.K., 2011.

12. Leip, A.; Achermann, B.; Billen, G.; Bleeker, A.; Bouwman, A.; de Vries, W.; Dragosits, U.; Doring, U.; Fernall, D.; Geupel, M.; Herolstab, j.; Johnes, P.; Le Gall, A. C.; Monni, S.; Neveceral, R.; Orlandini, L.; Prud'homme, M.; Reuter, H.; Simpson, D.; Seufert, G.; Spranger, T.; Sutton, M.; van Aardenne, J.; Voss, M. 
and Winiwarter, W. Integrating nitrogen fluxes at the European scale. In: Sutton, M.; Howard, C.; Erisman, J. W.; Billen, G.; Bleeker, A.; Greenfelt, P.; van Grinsven, H. Grizzette, B. (eds.) The European Nitrogen Assessment. 2011, Cambridge University Press, Cambridge, pp. 345-376.

13. Leip, A.; Weiss, F.; Lesschen, J. P.; Westhoek, H. The nitrogen footprint of food products in the European Union. J. Agri. Sci. 2014, 152(S1), 20-33.

14. Reactive Nitrogen in the United States: An Analysis of Inputs, Flows, Consequences, and Management Options; US Environmental Protection Agency (EPA): Washington, DC, 2011; http://terra.whrc.org/denitrification/WS4/WS4pdfs/Erisman.pdf.

15. Velthof, G.L.; Oudendag, D.; Witzke, H.P.; Asman, W.A.H.; Klimont, Z.; Oenema, O. Integrated assessment of nitrogen losses from agriculture in EU-27 using MITERRA-EUROPE. J. Environ. Qual. 2009, 38(2), 402-417.

16. Ma, L.; Ma, W. Q.; Velthof, G. L.; Wang, F. H.; Qin, W.; Zhang, F. S.; Oenema, O. Modeling nutrient flows in the food chain of China. J. Environ. Qual. 2010, 39(4), 1279-1289.

17. Klimont, Z., and C. Brink. Modelling of emissions of air pollutants and greenhouse gases from agricultural sources in Europe. IIASA IR 04-048. Int. Inst. for Applied Systems Analysis, Laxenburg, Austria. 2004.

18. Reidy, B.; Dämmgen, U.; Döhler, H.; Eurich-Menden, B.; Van Evert, F.K.; Hutchings, N.J.; Luesink,H.H.; Menzi, H.; Misselbrookg, T.H.; Montenyh, G.J.; Webb, J. Comparison of models used for national agricultural ammonia emission 
573 inventories in Europe: Liquid manure systems. Atmos Environ, 2008, 42(14), $574 \quad 3452-3464$.

575 19. Herrero, M.; Thornton, P. K. Livestock and global change: Emerging issues for 576 sustainable food systems. Proc. Natl. Acad. Sci. USA. 2013, 110(52), $577 \quad 20878-20881$.

578 20. MOA (Ministry of Agriculture).

579 http://www.gov.cn/xinwen/2015-03/18/content_2835617.htm. (Accessed in $580 \quad$ 2015).

581 21. MOA (Ministry of Agriculture). China Livestock Yearbook. (In Chinese.) China $582 \quad$ Agriculture Press, Beijing, 2013.

583 22. Food and Agriculture Organization (FAO).

$584 \quad$ http://faostat.fao.org/site/291/default.aspx. (Accessed in 2015).

585 23. Chadwick, D.; Jia, W.; Tong, Y.; Yang, G.; Shen, Q.; Chen, Q. Improving manure 586 nutrient management towards sustainable agricultural intensification in China. 587 Agr. Ecosyst. Environ. 2015, 209, 34-46.

588 24. Alexandratos N, Bruinsma J. World Agriculture Towards 2030/2050: The 2012

589 Revision. (2012) (Food and Agriculture Organization of the United Nations, 590 Rome).

591 25. SCOC (State Council of China). 2013, 592 http://www.gov.cn/flfg/2013-11/26/content_2535095.htm (Accessed in 2013). 593 26. Velthof, G. L.; Oudendag, D.; Witzke, H. P.; Asman, W. A. H.; Klimont, Z.;; 594 Oenema, O. Integrated assessment of nitrogen losses from agriculture in EU-27 
595

596

597

598

599

600

601

602

603

604

605

606

607

608

609

610

611

612

613

614

615

616

using MITERRA-EUROPE. J. Environ. Qual. 2009, 38(2), 402-417.

27. Yan, Z.; Liu, P.; Li, Y.; Ma, L.; Alva, A.; Dou, Z.; Chen, Q.; Zhang, F. Phosphorus in China's intensive vegetable production systems: Over fertilization, soil enrichment, and environmental implications. J. Environ. Qual. 2013, 42(4), 982-989.

28. Liu, X.; Jin, J.; Ren, T.; He, P. Potential of organic manures nutrient resources and their environmental risk in China. Chinese J Applied Ecology. 2010, 21(8), 2092-2098. (In Chinese).

29. Velthof, Gerard L.; Hou, Yong.;Oenema, Oene. Nitrogen excretion factors of livestock in the European Union: a review. J. Sci. Food. Agri. 2015, 95: 3004 3014.

30. Huang, X.; Song, Y.; Li, M.; Li, J.; Huo, Q.; Cai, X.; Zhu, T.; Hu, M.; Zhang, H. A high - resolution ammonia emission inventory in China. Global. Biogeochem. Cycles. 2012, 26(1), 1-14.

31. Chen, G. Q.; Zhang, B. Greenhouse gas emissions in China 2007: inventory and input-output analysis. Energy Policy. 2010, 38(10), 6180-6193.

32. Liu, X.; Sheng, H.; Jiang, S.; Yuan, Z.; Zhang, C.; Elser, J.J. Intensification of phosphorus cycling in China since the 1600s. Proc. Natl. Acad. Sci. USA. 2016, 113(10), 2609-2614.

33. (EPA) US Environmental Protection Agency. Reactive Nitrogen in the United States: An Analysis of Inputs, Flows, Consequences, and Management Options. 2011. 
617 34. Suh, S.; Yee, S. Phosphorus use-efficiency of agriculture and food system in the 618 US. Chemosphere. 2011, 84(6), 806-813.

619 35. Ott, C.; Rechberger, H. The European phosphorus balance. Resour. Conserv. Recy. $620 \quad 2012,60,159-172$.

621 36. Mishima, S.; Endo, A.; Kohyama, K. Recent trends in phosphate balance 622 nationally and by region in Japan. Nutr. Cycl. Agroecosys. 2010, 86(1), 69-77.

623 37. Mishima, S. I. The recent trend of agricultural nitrogen flow in Japan and 624 improvement plans. Nutr. Cycl. Agroecosys. 2002, 63(2-3), 151-163.

625 38. Oenema, O. Governmental policies and measures regulating nitrogen and 626 phosphorus from animal manure in European agriculture. J. Ani. Sci. 2004, 627 82(13_suppl), E196-E206.

628 39. Centner, T.J. Evolving policies to regulate pollution from animal feeding 629 operations. Environ. Manage. 2001, 28(5), 599-609.

630 40. Centner, T.J.; Feitshans, T.A. Regulating manure application discharges from 631 concentrated animal feeding operations in the United States. Environ. Pollut. $632 \quad$ 2006, 141(3), 571-573.

633 41. Brinkhorst, L.J.; Pronk, J.P. Integrale aanpak mestproblematiek. Kamerstuk 634 1999-2000, 26729 (13) (in Dutch). 1999.

635 42. Velthof, G.L.; Lesschen, J.P.; Webb, J.; Pietrzak, S.; Miatkowski, Z.; Pinto, M.; 636 Kros, J.; Oenema, O. The impact of the Nitrates Directive on nitrogen emissions 637 from agriculture in the EU-27 during 2000-2008. Sci. Total. Environ. 2014, $638 \quad 468-469$, p. $1225-1233$. 
639

640

641

642

643

644

645

646

647

648

649

650

651

652

653

654

655

656

657

658

659

660

43. The Control of Pollution (Silage, Slurry and Agricultural Fuel Oil) Regulations 1991 (SI No 324), and as amended 1997 (SI No 547).

44. Meng, X.; Zhang, J.; Li, P.; Chen, X. Summary of Livestock Environmental Pollution and Environmental Management Policies. Journal of Ecology and Rural Environment. 2014, 30(1), 1-8. (In Chinese).

45. Ma, L.; Wang, F.; Zhang, W.; Ma, W.; Velthof, G.; Qin, W.; Oenema, O.; Zhang, F. Environmental assessment of management options for nutrient flows in the food chain in China. Environmental Science \& Technology. 2013, 47(13), 7260-7268.

46. Luesink, H.; Blokland, P.; Daatselaar, C. Monitoring mestmarkt, Den Haag: LEI notitie. 2014.

47. Zhang, K.; Yu, Z.; Li, X.; Zhou, W.; Zhang, D. Land use change and land degradation in China from 1991 to 2001. Land Degradation Development. 2007, 18(2), 209-219.

48. Jia, W.; Yan, Z.; Chadwick, D. R.; Kang, L.; Duan, Z.; Bai, Z.; Chen, Q. Integrating soil testing phosphorus into environmentally based manure management in peri-urban regions: A case study in the Beijing area. Agric., Ecosyst. Environ, 2015, 209, 47-59.

49. Wei, R.; Ge, F.; Huang, S.; Chen, M.; Wang, R. Occurrence of veterinary antibiotics in animal wastewater and surface water around farms in Jiangsu Province, China. Chemosphere. 2011, 82(10), 1408-1414.

50. Zhao, L.; Dong, Y. H.; Wang, H. Residues of veterinary antibiotics in manures from feedlot livestock in eight provinces of China. Sci. Total Environ. 2010, 
$661 \quad 408(5), 1069-1075$.

662 51. Wang, H.; Wang, B.; Zhao, Q.; Zhao, Y.; Fu, C.; Feng, X.; Wang, N.; Su, M.;

663 Tang, C.; Jiang, F.; Zhou Y.; Chen, Y.; Jiang, Q. Antibiotic Body Burden of

664 Chinese School Children: A Multisite Biomonitoring-based Study. Environ. Sci.

665 Technol. 2015, 49(8), 5070-5079.

666 
667 Table 1. Manure nitrogen $(\mathrm{N})$ and phosphorus $(\mathrm{P})$ excretion, utilization in crop land, 668 and losses in United States of America (USA), Europe (EU), Japan and China.

\begin{tabular}{|c|c|c|c|c|c|c|c|c|}
\hline \multirow{2}{*}{ Year } & \multicolumn{2}{|c|}{ USA } & \multicolumn{2}{|c|}{ EU } & \multicolumn{2}{|c|}{ Japan } & \multicolumn{2}{|c|}{ China** } \\
\hline & $2002^{33}$ & $2007^{34}$ & $2000^{12}$ & $2000^{35}$ & $2005^{36}$ & $2005^{37}$ & 2010 & 2010 \\
\hline & $\mathrm{N}$ & $\mathrm{P}$ & $\mathrm{N}$ & $\mathrm{P}$ & $\mathrm{N}$ & $\mathrm{P}$ & $\mathrm{N}$ & $\mathrm{P}$ \\
\hline Excretion (Tg) & 6.8 & 1.7 & 10.4 & 4.2 & 0.73 & 0.19 & 22.8 & 4.6 \\
\hline Utilization (Tg) & 5.0 & 1.3 & 8.4 & 4.2 & 0.51 & 0.15 & 7.5 & 2.3 \\
\hline Losses $(\mathrm{Tg})^{*}$ & 1.8 & 0.4 & 2.0 & 0.01 & 0.23 & 0.04 & 15.3 & 2.3 \\
\hline
\end{tabular}

$669 *$ Not including losses after manure application to crop land.

$670 * *$ This study.

671 


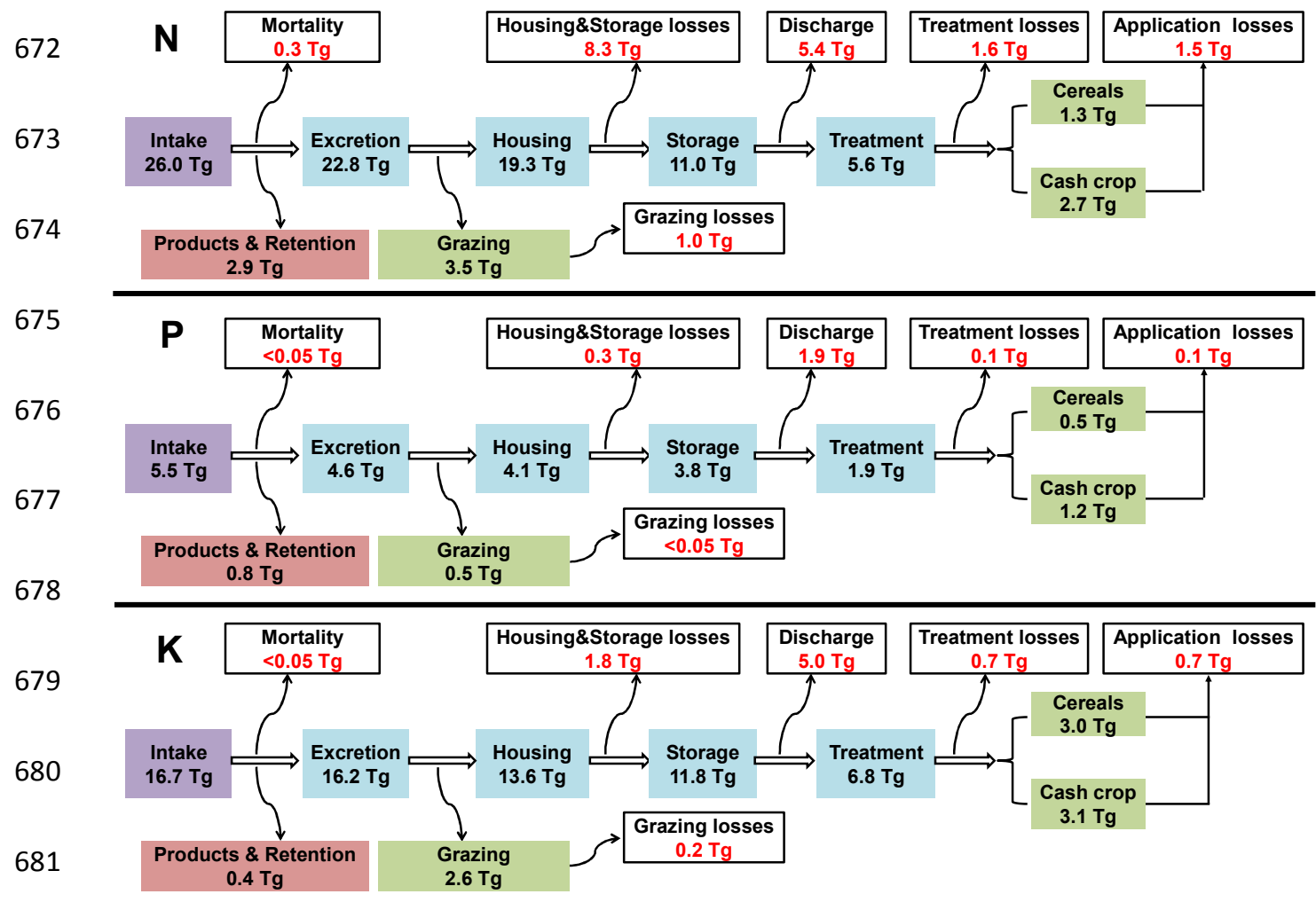

682 Figure 1. The nitrogen $(\mathrm{N})$, phosphorus $(\mathrm{P})$ and potassium $(\mathrm{K})$ flows through the

683 manure management chain in China in 2010.

684 Discharge, direct discharge of manure to water body or landfill.

685 


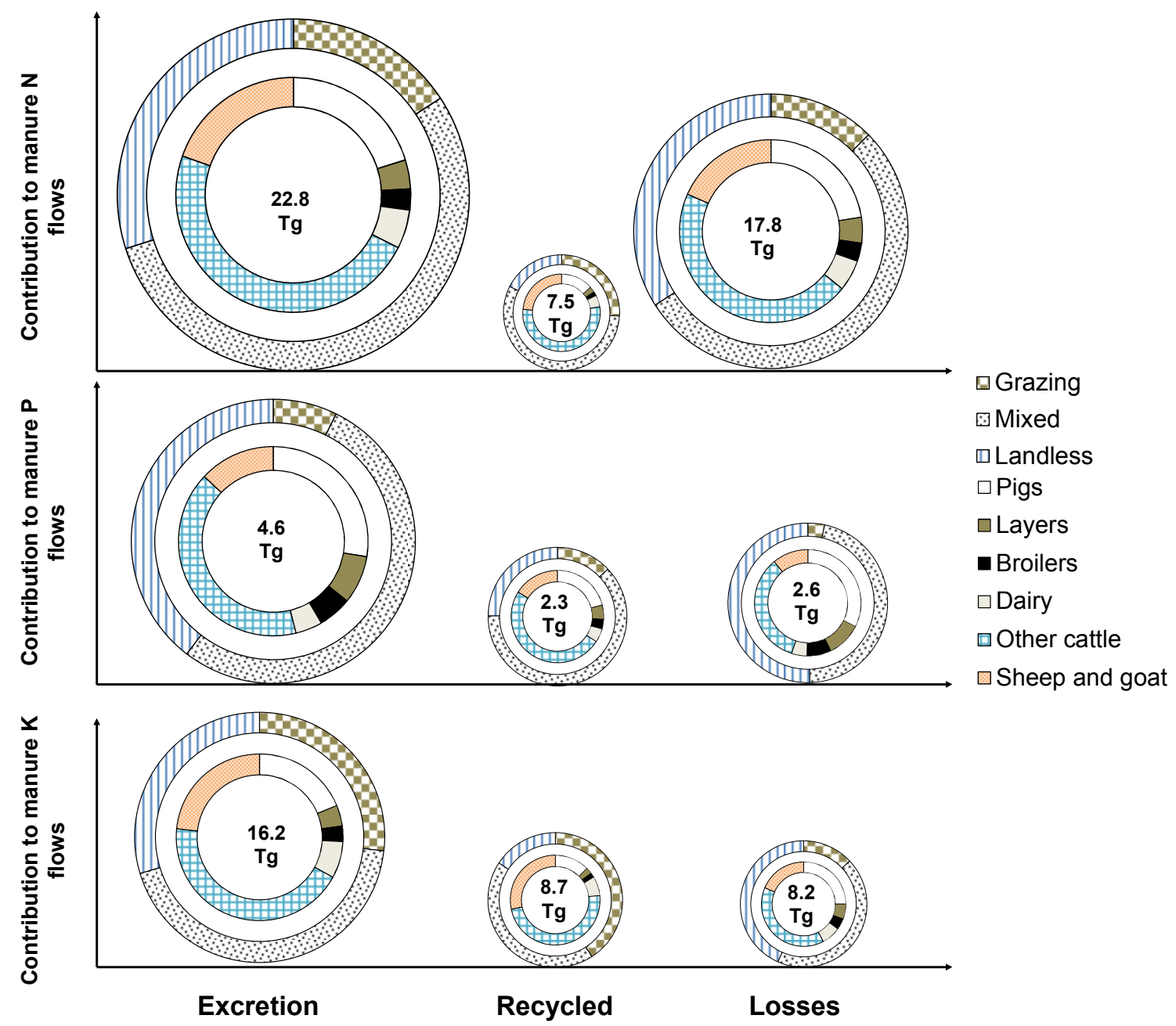

699 Figure 2. The relative contribution of different animal production systems (outside

700 circle) and animal categories (inner circle) to the total manure nitrogen $(\mathrm{N})$,

701 phosphorus (P) and potassium (K) excretion, recycling to agriculture land and losses

702 to the environment from livestock production in China in 2010. 


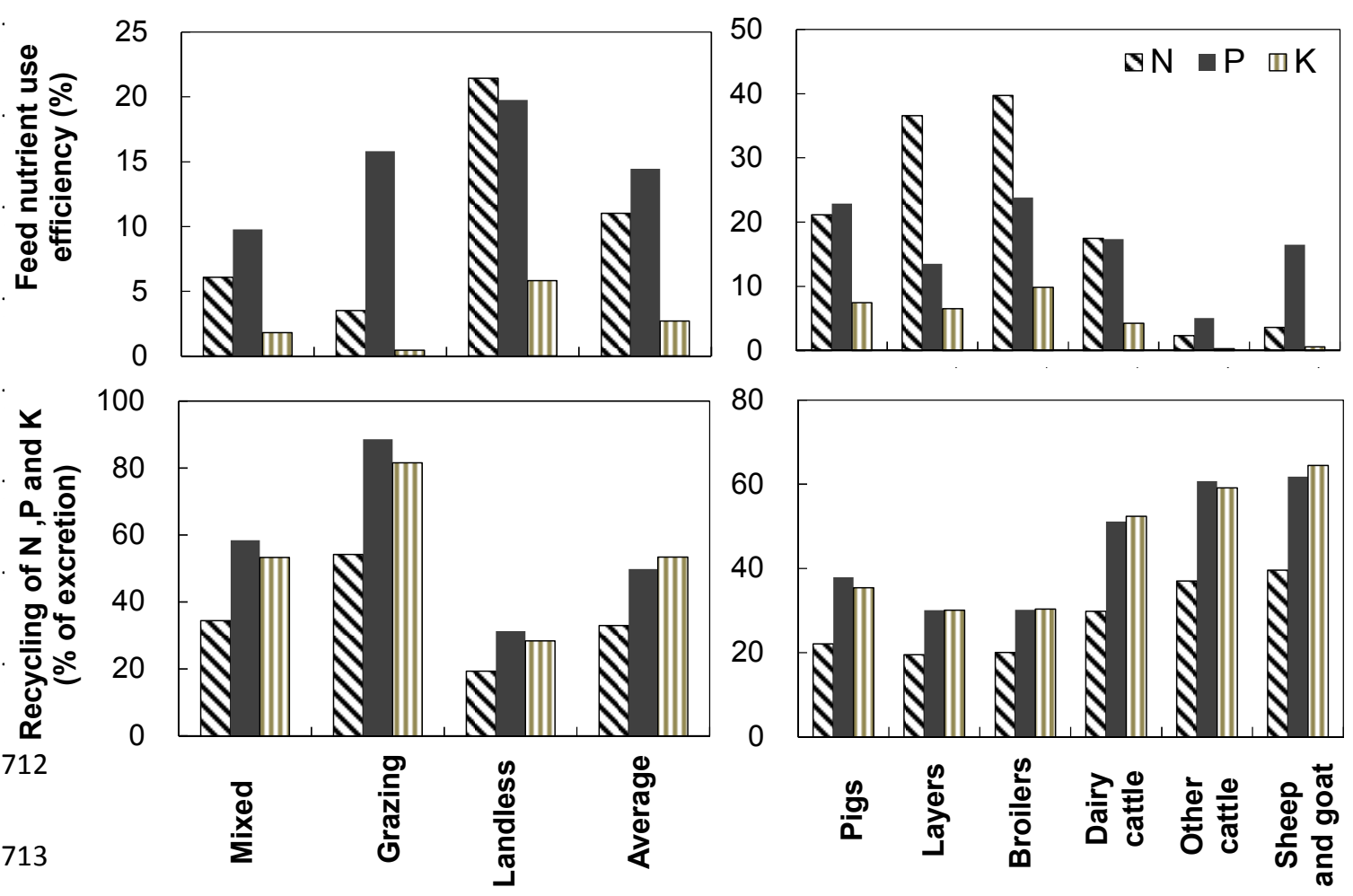

714 Figure 3. The nitrogen $(\mathrm{N})$, phosphorus $(\mathrm{P})$ and potassium $(\mathrm{K})$ use efficiencies at the

715 herd level for different production systems (a), and animal categories (b), recycling

716 rate of excreted $\mathrm{N}, \mathrm{P}$ and $\mathrm{K}$ for different production systems (c), and animal categories

$717(d)$. 

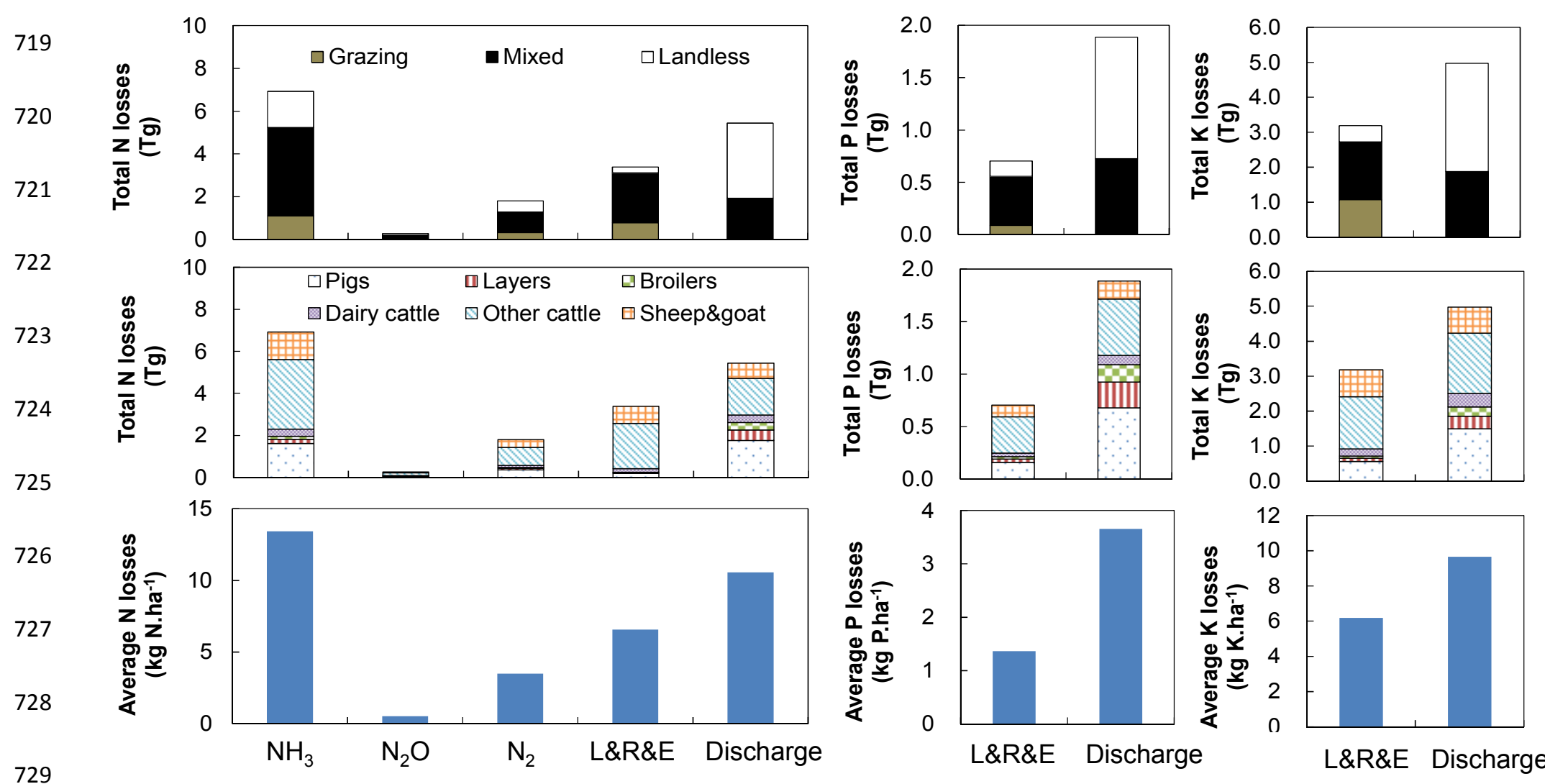

730

Figure 4. The contribution of the different animal categories and production systems to the total nitrogen (N), phosphorus (P) and potassium (K) 


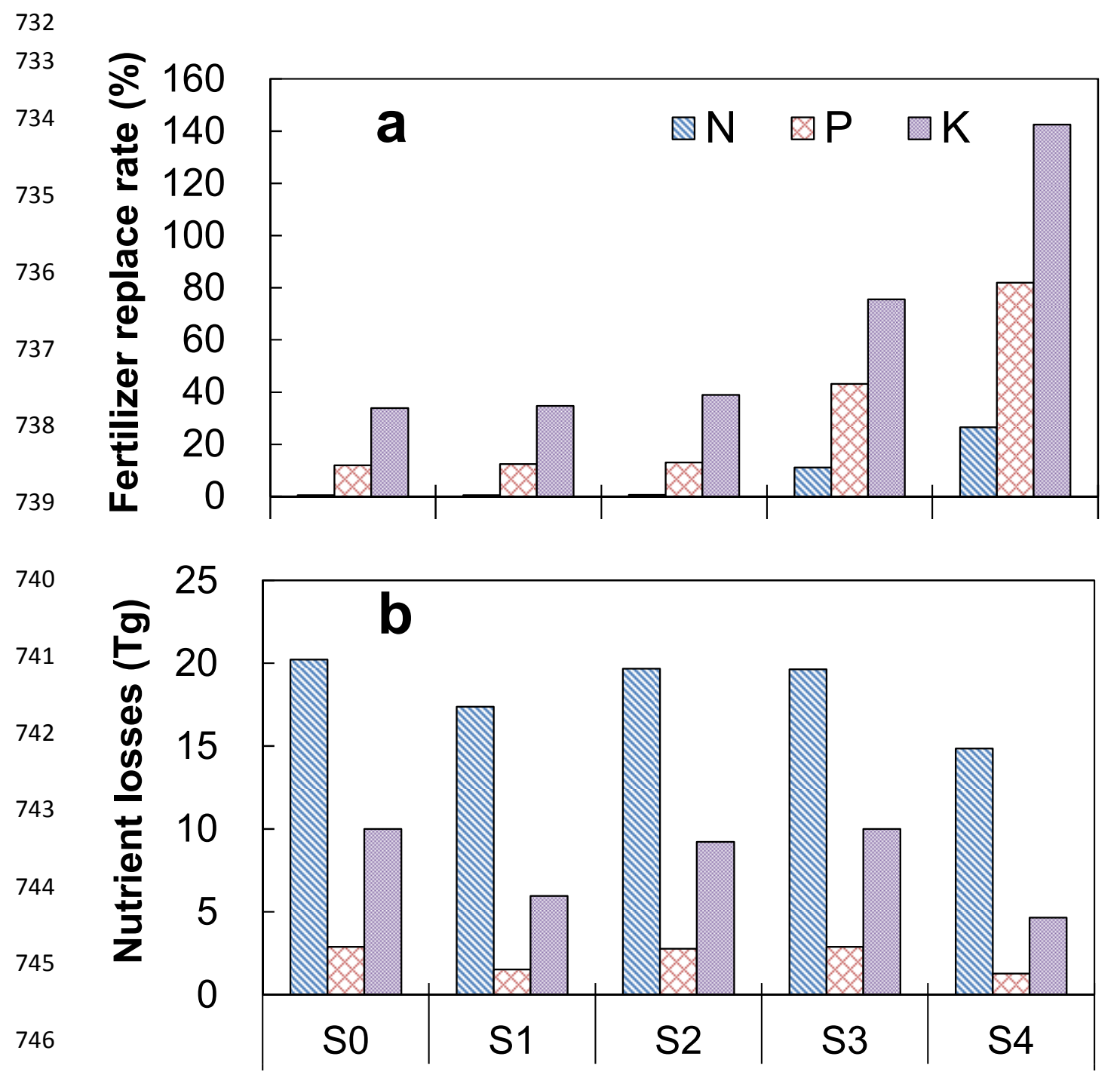

747 Figure 5. The chemical nitrogen $(\mathrm{N})$, phosphorus $(\mathrm{P})$, and potassium $(\mathrm{K})$ fertilizer

748 replacement by manure (a), and N, P and $\mathrm{K}$ losses in the manure management chain (b)

749 in different scenarios in 2020.

750 S0, business as usual in 2020; S1, promote application of manure and prohibit discharge of

751 manure; S2, improving manure collection in the housing and storage; S3, improving manure

752 application; S4, Combination of S1-S3. 